\title{
Stable carbon isotope fractionation by marine phytoplankton in response to daylength, growth rate, and $\mathrm{CO}_{2}$ availability
}

\author{
Steffen Burkhardt", Ulf Riebesell, Ingrid Zondervan \\ Alfred Wegener Institute for Polar and Marine Research, Am Handelshafen 12, D-27570 Bremerhaven, Germany
}

\begin{abstract}
Stable carbon isotope fractionation $\left(\varepsilon_{\mathrm{p}}\right)$ of 7 marine phytoplankton species grown in different irradiance cycles was measured under nutrient-replete conditions at a high light intensity in batch cultures. Compared to experiments under continuous light, all species exhibited a significantly higher instantaneous growth rate $\left(\mu_{\mathrm{i}}\right)$, defined as the rate of carbon fixation during the photoperiod, when cultivated at $12: 12 \mathrm{~h}, 16: 8 \mathrm{~h}$, or 18:6 h light:dark (L/D) cycles. Isotopic fractionation by the diatoms Skeletonema costatum, Asterionella glacialis, Thalassiosira punctigera, and Coscinodiscus wailesii (Group I) was 4 to $6 \%$ lower in a $16: 8 \mathrm{~h} \mathrm{~L} / \mathrm{D}$ cycle than under continuous light, which we attribute to differences in $\mu_{\mathrm{i}}$. In contrast, $\varepsilon_{\mathrm{p}}$ in Phaeodactylum tricornutum, Thalassiosira weissflogii, and in the dinoflagellate Scrippsiella trochoidea (Group II) was largely insensitive to daylength-related differences in instantaneous growth rate. Since other studies have reported growth-rate dependent fractionation under $\mathrm{N}$-limited conditions in $P$. tricornutum, $\mu_{\mathrm{i}}$-related effects on fractionation apparently depend on the factor controlling growth rate. We suggest that a general relationship between $\varepsilon_{\mathrm{p}}$ and $\mu_{\mathrm{i}} /\left[\mathrm{CO}_{2, \text { aq }}\right]$ may not exist. For 1 species of each group we tested the effect of variable $\mathrm{CO}_{2}$ concentration, $\left[\mathrm{CO}_{2, \mathrm{aq}}\right]$, on isotopic fractionation. A decrease in $\left[\mathrm{CO}_{2, \mathrm{aq}}\right]$ from ca 26 to $3 \mu \mathrm{mol} \mathrm{kg}^{-1}$ caused a decrease in $\varepsilon_{p}$ by less than $3 \%$. This indicates that variation in $\mu_{i}$ in response to changes in daylength has a similar or even greater effect on isotopic fractionation than $\left[\mathrm{CO}_{2, a q}\right]$ in some of the species tested. In both groups $\varepsilon_{\mathrm{p}}$ tended to be higher in smaller species at comparable growth rates. In 24 and $48 \mathrm{~h}$ time series the algal cells became progressively enriched in ${ }^{13} \mathrm{C}$ during the day and the first hours of the dark period, followed by ${ }^{13} \mathrm{C}$ depletion in the $2 \mathrm{~h}$ before beginning of the following light period. The daily amplitude of the algal isotopic composition $\left(\delta^{13} \mathrm{C}\right)$, however, was $\leq 1.5 \%$, which demonstrates that diurnal variation in $\delta^{13} \mathrm{C}$ is relatively small.
\end{abstract}

KEY WORDS: Isotope fractionation $\cdot{ }^{13} \mathrm{C}$ discrimination Growth rate $\cdot \mathrm{CO}_{2} \cdot$ Paleobarometer Daylength $\cdot$ Diurnal variation $\cdot$ Diatoms $\cdot$ Phytoplankton

\section{INTRODUCTION}

The stable carbon isotopic composition $\left(\delta^{13} \mathrm{C}\right)$ of marine phytoplankton depends on both the environmental conditions and the physiology of algal cells. It is determined by (1) the isotopic composition of the inorganic carbon source, (2) enzymatic isotope fractionation during inorganic carbon fixation, and (3) further modification of $\delta^{13} \mathrm{C}$ of assimilated carbon compounds during carboxylation/decarboxylation reactions in res-

·E-mail: sburkhardt@awi-bremerhaven.de piration and secondary biosynthetic pathways. Knowledge of the relative contribution of each of these factors to natural variability in $\delta^{13} \mathrm{C}$ is required to interpret distributions of stable isotopes in marine plankton.

A systematic depletion in ${ }^{13} \mathrm{C}$ relative to ${ }^{12} \mathrm{C}$ in both plankton and sediment organic carbon from low to higher latitudes was first reported by Sackett et al. (1965) and has been confirmed in subsequent studies (e.g. Sackett et al. 1974, Rau et al. 1982, 1989). Covariance of $\delta^{13} \mathrm{C}$ of suspended particulate organic matter with concentrations of dissolved molecular carbon dioxide $\left(\left[\mathrm{CO}_{2, \mathrm{aq}}\right]\right)$ in ocean surface waters led to the suggestion that ambient $\mathrm{CO}_{2}$ concentrations might be 
the major determinant of $\delta^{13} \mathrm{C}$ in marine phytoplankton (e.g. Deuser et al. 1968, Rau et al. 1989, 1992). If $\left[\mathrm{CO}_{2, a q}\right]$ controls $\delta^{13} \mathrm{C}$ values in primary produced organic matter and if little modification occurs during sedimentation, variation in the isotopic composition of organic compounds in the sedimentary record could serve as a 'paleobarometer' to reconstruct $\mathrm{CO}_{2}$ concentrations in sea surface water over geologic time scales (e.g. Jasper \& Hayes 1990, Freeman \& Hayes 1992, Jasper et al. 1994, Rau 1994).

Several lines of evidence, however, indicate that factors other than $\mathrm{CO}_{2}$ concentration may also account for significant variability of $\delta^{13} \mathrm{C}$ in plankton. In the field, differences between species and differences in growth rates $(\mu)$, which further depend on environmental factors such as temperature, light intensity and nutrient supply, may be similar in importance to $\left[\mathrm{CO}_{2, \mathrm{aq}}\right]$ in affecting the isotopic composition of marine phytoplankton (e.g. Francois et al. 1993, Goericke \& Fry 1994, Pancost et al. 1997, Kukert \& Riebesell 1998).

Several models of photosynthetic ${ }^{13} \mathrm{C}$ fractionation in marine microalgae based on diffusive molecular $\mathrm{CO}_{2}$ uptake demonstrate that species-specific parameters can play a significant role in accounting for observed variations of $\delta^{13} \mathrm{C}$ in oceanic plankton (e.g. Francois et al. 1993, Goericke et al. 1994, Laws et al. 1995, 1997. Rau et al. 1996, 1997, Popp et al. 1998). Such parameters include $\mathrm{CO}_{2}$ permeability of the cell membrane, enzymatic fractionation, cellular carbon content, and the cell surface area to volume ratio.

Laboratory experiments with the diatoms Phaeodactylum tricornutum (Laws et al. 1995), Porosira glacialis (Popp et al. 1998), and the coccolithophorid Emiliania huxleyi (Bidigare et al. 1997) in nitrate-limited continuous cultures reveal a highly significant, linear inverse relationship between isotopic fractionation $\left(\varepsilon_{\mathrm{p}}\right)$ and the ratio of growth rate and $\left[\mathrm{CO}_{2, \text { aq }}\right]$ at $\mathrm{CO}_{2}$ concentrations

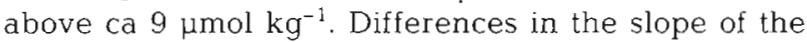
regression lines can be accounted for by differences in the surface area and carbon content of the cells (Popp et al. 1998). Such correlation is in accordance with the theory of diffusive uptake of $\mathrm{CO}_{2}$ during algal growth, but might be equally well explained by an active trans. port mechanism of either $\mathrm{CO}_{2}$ or $\mathrm{HCO}_{3}{ }^{-}$into the cell (Keller \& Morel 1999). Regardless of the mechanism of inorganic carbon uptake, this relationship may be applicable in the field to estimate growth rates from measurements of $\delta^{13} \mathrm{C}$ and $\left[\mathrm{CO}_{2, \mathrm{aq}}\right]$ if the linear dependence of $\varepsilon_{\mathrm{p}}$ on $\mu /\left[\mathrm{CO}_{2, \mathrm{aq}}\right]$ proves to be a general phenomenon.

In the above-mentioned experiments, growth rate and $\left[\mathrm{CO}_{2, \mathrm{aq}}\right]$ were varied simultaneously so that it is not possible to distinguish between growth rate effects, $\mathrm{CO}_{2}$ effects and their relative contribution to variability in $\varepsilon_{\mathrm{p}}$. Similarly, $\left[\mathrm{CO}_{2, \mathrm{aq}}\right]$ was not constant in experi- ments by Fry \& Wainright (1991), who reported a linear inverse relationship between $\varepsilon_{p}$ and $\mu$. Interpretation of their data is further complicated by differences in species composition in mixed cultures dominated by either fast-growing diatoms or slow-growing dinoflagellates.

It is also important to keep in mind that isotopic fractionation reflects carbon assimilation during the photoperiod (Laws et al. 1995). Thus, growth rate estimates should account for light:dark (L/D) cycles by calculating instantaneous growth rates $\left(\mu_{i}\right)$ from $24 \mathrm{~h}$ average growth rates $\left(\mu_{\mathrm{L}+\mathrm{D}}\right)$. Instantaneous rates of carbon assimilation in the light may differ by a factor of up to 2 between algae grown at different L/D cycles when their $24 \mathrm{~h}$ average growth rate is the same. Under natural conditions, large latitudinal and seasonal differences in daylength exist. Considering an algal cell growing at $12 \mathrm{~h}$ of daylight in equatorial surface waters at the same $24 \mathrm{~h}$ average rate as under near-continuous light conditions during summer at high latitudes, it needs to assimilate $\mathrm{CO}_{2}$ at approximately twice the rate.

It is the main goal of our study to quantify the effect of variable growth rate on stable carbon isotopic fractionation at constant $\left[\mathrm{CO}_{2, \text { aq }}\right]$ and compare $\mu$-dependent changes in $\varepsilon_{\mathrm{p}}$ between several species of marine phytoplankton of different sizes under controlled laboratory conditions. For this purpose we incubated 6 diatom and 1 dinoflagellate species in diluted batch cultures at $15^{\circ} \mathrm{C}$ under nutrient replete conditions at a high light intensity. Concentrations of $\mathrm{CO}_{2, a q}$ were adjusted to $25-37 \mu \mathrm{mol} \mathrm{kg}{ }^{-1}$, which is approximately 2 to 3 times the concentration in natural seawater at that temperature. Variation in growth rates was achieved by acclimating the algae to different $L / D$ cycles. This approach makes use of the ability of many marine phytoplankton species to keep their $24 \mathrm{~h}$ average growth rate relatively constant, independent of duration of the photoperiod (Brand \& Guillard 1981). Consequently, $\mu_{\mathrm{i}}$ during the photoperiod increases when algae are transferred from continuous light to a L/D cycle

In additional experiments, the effect of variable $\left[\mathrm{CO}_{2, a q}\right]$ on $\varepsilon_{\mathrm{p}}$ at constant $\mu_{\mathrm{j}}$ was measured in 2 of the diatom species which exhibited little variation in growth rate between $\mathrm{CO}_{2}$ concentrations of $\mathrm{ca} 3$ and $25 \mu \mathrm{mol} \mathrm{kg}^{-1}$. Furthermore, diurnal variation in $\delta^{13} \mathrm{C}$ of these diatoms was monitored in $2 \mathrm{~h}$ intervals to determine the potential impact of metabolic processes such as respiration and biosynthesis in the dark on the isopic composition of the diatom cultures. Differences in the response of $\varepsilon_{\mathrm{p}}$ to variation in $\mu_{i}$ and $\left[\mathrm{CO}_{2, \mathrm{aq}}\right]$ between individual species in our study are discussed with respect to possible mechanisms and pathways of inorganic $\mathrm{C}$ acquisition in marine phytoplankton. 


\section{MATERIALS AND METHODS}

Experiments. Dilute batch cultures of the marine diatom species Skeletonema costatum, Thalassiosira weissflogii, Thalassiosira punctigera, Phaeodactylum tricornutum, Asterionella glacialis, Coscinodiscus wailesii, and of the marine dinoflagellate Scrippsiella trochoidea were grown in Rumed 1200 light-thermostats at a temperature of $15^{\circ} \mathrm{C}$ and an incident photon flux density of $150 \mu \mathrm{mol}$ photons $\mathrm{m}^{-2} \mathrm{~s}^{-1}$. The growth medium consisted of $0.2 \mu \mathrm{m}$ filtered, nutrient-enriched natural seawater with nitrate, silicate, and phosphate concentrations of 100,100 , and $6.25 \mu \mathrm{mol} \mathrm{kg}{ }^{-1}$, respectively. Trace metals, EDTA, and vitamins were added according to $\mathrm{f} / 2$-enrichment (Guillard \& Ryther 1962). Depending on the batch of seawater, salinity varied between 30.5 and 31.5 psu. Stock cultures were preadapted to experimental conditions of the respective treatments for at least 9 cell divisions.

All experiments were performed in $2.4 \mathrm{l}$ borosilicate glass bottles, sealed with PBT-lined screw caps. Initial tests indicated that, after inoculation at low cell concentrations, photosynthetic fixation of $\mathrm{CO}_{2}$ in the closed experimental system caused an increase in $\mathrm{pH}$ by $\leq 0.05$ when cells where harvested at concentrations equiva-

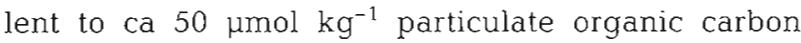
(POC). To minimize $\mathrm{pH}$ drift and associated shifts in carbon speciation, cells in all treatments were typically harvested at POC concentrations of 20 to $30 \mu \mathrm{mol} \mathrm{kg} \mathrm{kg}^{-1}$. Another reason to avoid dense cultures is a concomitant change in $\delta^{13} \mathrm{C}$ of dissolved inorganic carbon (DIC) during discrimination against ${ }^{13} \mathrm{C}$ in photosynthesis. In our dilute cultures, changes in the isotopic composition of DIC never exceeded $0.4 \%$ during the experiments.

Prior to the experiments, growth rates were determined for adapted cells and cellular carbon content was estimated from cell volume according to Strathmann (1967). This information together with measurements of cell concentrations of the pre-cultures was used to calculate the appropriate amount of inoculum for each bottle to permit ca 9 cell divisions before the target concentration of $<50 \mu \mathrm{mol} \mathrm{kg}^{-1}$ POC was reached and the experiment was terminated. In all of these experiments, cells were harvested at the same time of the day, corresponding to the end of the $16 \mathrm{~h}$ photoperiod. Microscopical analyses of subsamples indicated that bacterial biomass never exceeded $1 \%$ of algal biomass in the cultures and its contribution to total POC was therefore considered negligible.

Skeletonema costatum and Thalassiosira weissflogii were used to monitor diurnal variation in $\delta^{13} \mathrm{C}$ over a 24 or a $48 \mathrm{~h}$ time period. The 12 or 24 bottles required for each treatment of a time series were inoculated with pre-adapted diatom culture simultaneously in such a way that the appropriate concentration of POC of $<50 \mu \mathrm{mol} \mathrm{kg} \mathrm{kg}^{-1}$ was reached at the time of sampling. In all treatments, samples for the parameters of interest were then taken at $2 \mathrm{~h}$ intervals. For that purpose, incubation bottles were harvested completely and subsamples were used for chemical and microscopical analysis. In treatments including a dark phase, the first sample was taken at the beginning of the light period. Variable concentrations of $\mathrm{CO}_{2 \text {,aq }}$ ranging from 2.6 to $25.8 \mu \mathrm{mol} \mathrm{kg} \mathrm{kg}^{-1}$, were obtained by adjusting $\mathrm{pH}$ with $1 \mathrm{~N} \mathrm{HCl}$ or $1 \mathrm{~N} \mathrm{NaOH}$ to values between 7.97 and 8.87 (Table 1). S. costatum was grown at L/D cycles of $12: 12,16: 8$, and $24: 0 \mathrm{~h} . T$. weissflogii was grown at L/D cycles of 18:6 and 24:0 h. All other species were incubated at high $\left[\mathrm{CO}_{2, \mathrm{aq}}\right]$ of 30.1 to $37.7 \mu \mathrm{mol} \mathrm{kg}{ }^{-1}$ at both 16:8 and 24:0 h L/D cycles (Table 1).

Carbonate system. Experimental $\mathrm{CO}_{2}$ concentrations (Table 1) were adjusted by changing the relative proportions of the inorganic carbon species $\mathrm{CO}_{2, \text { aq }}$, $\mathrm{HCO}_{3}^{-}$, and $\mathrm{CO}_{3}^{2-}$ through addition of $\mathrm{HCl}$ or $\mathrm{NaOH}$. This causes $\mathrm{pH}$ to vary together with $\left[\mathrm{CO}_{2, \mathrm{aq}}\right]$ and alkalinity at constant DIC concentration. Lower $\mathrm{pH}$ favors equilibrium reactions between $\mathrm{CO}_{2}$ and $\mathrm{HCO}_{3}{ }^{-}$in the direction of $\mathrm{CO}_{2}$. Minor variation in DIC between treatments listed in Table 1 resulted from differences between seawater batches and from some $\mathrm{CO}_{2}$ gas exchange after manipulating the carbonate system before the bottles were closed. It should be pointed out that the approach chosen in other studies (e.g. Laws et al. 1995, Johnston 1996, Bidigare et al. 1997), in which $\left[\mathrm{CO}_{2, a q}\right]$ is manipulated by aeration at different $\mathrm{CO}_{2}$-levels, results in similar changes in $\mathrm{pH}$ upon $\left[\mathrm{CO}_{2, \mathrm{aq}}\right]$ variation as in our treatments. In an aerated system, however, alkalinity remains constant at variable DIC.

$\left[\mathrm{CO}_{2, \mathrm{aq}}\right]$ was calculated from DIC concentrations, total alkalinity (tAlk), temperature, salinity, and concentrations of phosphate and silicate assuming dissociation constants according to Mehrbach et al. (1973). DIC was measured in duplicate by coulometric titration, tAlk was determined in duplicate by Gran-titration, and $\mathrm{pH}$ was both calculated from DIC and tAlk and measured potentiometrically. For a detailed description of the methods see Burkhardt \& Riebesell (1997).

Stable carbon isotope fractionation. Samples were filtered using precombusted $\left(500^{\circ} \mathrm{C}, 12 \mathrm{~h}\right)$ Whatman $\mathrm{GF} / \mathrm{C}$ glass fiber filters. All filters were acidified with $0.1 \mathrm{~N} \mathrm{HCl}$ prior to measurements and dried for $12 \mathrm{~h}$ at $60^{\circ} \mathrm{C}$. Analysis of isotopic composition of particulate organic carbon $\left(\delta^{13} \mathrm{C}_{\text {poc }}\right)$ was performed in duplicate on a mass spectrometer (ANCA-SL 20-20 Europa Scientific). Isotopic composition of dissolved inorganic carbon $\left(\delta^{13} \mathrm{C}_{\text {DiC }}\right)$ was analyzed on unfiltered subsamples, preserved with $\mathrm{HgCl}_{2}$ (3.5\% w/v final concentration), with a Finnegan MAT Delta-S mass spectrometer after acidification with $100 \% \mathrm{H}_{3} \mathrm{PO}_{4}$ at $25^{\circ} \mathrm{C}$ in a vacuum extraction line, as described by Mackensen et al. (1996). The 
Table 1. Experimental conditions, isotope measurements, and growth rate estimates during dilute batch culture incubations of 7 marine phytoplankton species. Results for Skeletonema costatum and Thalassiosira weissflogii are mean values of 24 or 48 h time series (see text for definition of variables)

\begin{tabular}{|c|c|c|c|c|c|c|c|c|c|c|}
\hline Species & $\begin{array}{l}\mathrm{L} / \mathrm{D} \\
(\mathrm{h}: \mathrm{h})\end{array}$ & $\begin{array}{c}\text { DIC } \\
\left(\mathrm{mmol} \mathrm{kg}^{-1}\right)\end{array}$ & $\begin{array}{c}\text { tAlk } \\
\left(\text { meq } \mathrm{kg}^{-1}\right)\end{array}$ & $\mathrm{pH}$ & $\begin{array}{c}{\left[\mathrm{CO}_{2, \mathrm{dq}}\right]} \\
\left(\mu \mathrm{mol} \mathrm{kg}^{-1}\right)\end{array}$ & $\begin{array}{c}\delta^{13} \mathrm{C}_{\mathrm{CO}_{2}} \\
(\%))\end{array}$ & $\begin{array}{c}\delta^{13} \mathrm{C}_{\mathrm{POC}} \\
(\%)\end{array}$ & $\begin{array}{c}\varepsilon_{p} \\
(\% o)\end{array}$ & $\begin{array}{l}\mu_{L+D} \\
\left(d^{-1}\right)\end{array}$ & $\begin{array}{c}\mu_{1} \\
\left(d^{-1}\right)\end{array}$ \\
\hline \multicolumn{11}{|l|}{ Group I } \\
\hline \multirow[t]{6}{*}{ Skeletonema costatum } & $12: 12$ & 2.11 & 2.31 & 8.14 & 17.3 & -10.7 & -17.6 & 7.0 & 1.6 & 3.8 \\
\hline & $16: 8$ & 2.10 & 2.90 & 8.87 & 2.6 & -10.7 & -16.8 & 6.2 & 2.0 & 3.3 \\
\hline & $16: 8$ & 2.11 & 2.31 & 8.14 & 17.3 & -10.7 & -18.0 & 7.4 & 2.1 & 3.4 \\
\hline & $16: 8$ & 2.10 & 2.23 & 7.98 & 25.5 & -10.7 & -18.5 & 8.0 & 2.1 & 3.4 \\
\hline & $24: 0$ & 2.10 & 2.90 & 8.87 & 2.6 & -10.7 & -22.9 & 12.4 & 1.7 & 1.7 \\
\hline & $24: 0$ & 2.10 & 2.23 & 7.98 & 25.5 & -10.7 & -24.5 & 14.1 & 1.9 & 1.9 \\
\hline \multirow[t]{2}{*}{ Asterionella glacialis } & $16: 8$ & 2.14 & 2.24 & 7.86 & 33.8 & -10.4 & -18.3 & 8.1 & 1.8 & 2.9 \\
\hline & $24: 0$ & 2.14 & 2.24 & 7.86 & 33.8 & -10.4 & -22.2 & 12.1 & 1.7 & 1.7 \\
\hline \multirow{2}{*}{ Thalassiosira punctigera } & $16: 8$ & 2.06 & 2.19 & 7.90 & 30.1 & -10.0 & -17.0 & 7.1 & 0.8 & 1.3 \\
\hline & $24: 0$ & 2.06 & 2.19 & 7.90 & 30.1 & -10.0 & -21.9 & 12.1 & 0.9 & 0.9 \\
\hline Coscinodiscus wailesii & $24: 0$ & 2.08 & 2.15 & 7.83 & 35.7 & -10.2 & -17.7 & 7.6 & 0.3 & 0.3 \\
\hline \multicolumn{11}{|l|}{ Group II } \\
\hline \multirow[t]{2}{*}{ Phaeodactylum tricornutum } & $16: 8$ & 2.05 & 2.10 & 7.80 & 37.7 & -10.3 & -25.9 & 16.0 & 1.4 & 2.3 \\
\hline & $24: 0$ & 2.05 & 2.10 & 7.80 & 37.7 & -10.3 & -26.6 & 16.7 & 1.6 & 1.6 \\
\hline \multirow[t]{4}{*}{ Thalassiosira weissflogii } & $18: 6$ & 2.09 & 2.76 & 8.75 & 3.5 & -10.7 & -22.5 & 12.0 & 1.5 & 2.1 \\
\hline & $18: 6$ & 2.07 & 2.19 & 7.97 & 25.8 & -10.7 & -25.0 & 14.6 & 1.5 & 2.1 \\
\hline & $24: 0$ & 2.09 & 2.76 & 8.75 & 3.5 & -10.7 & -22.5 & 12.1 & 1.6 & 1.6 \\
\hline & $24: 0$ & 2.07 & 2.19 & 7.97 & 25.8 & -10.7 & -24.6 & 14.3 & 1.6 & 1.6 \\
\hline \multirow[t]{2}{*}{ Scrippsiella trochoidea } & $16: 8$ & 2.08 & 2.15 & 7.83 & 35.7 & -10.2 & -19.8 & 9.7 & 0.6 & 0.9 \\
\hline & $24: 0$ & 2.08 & 2.15 & 7.83 & 35.7 & -10.2 & -18.3 & 8.2 & 0.6 & 0.6 \\
\hline
\end{tabular}

carbon isotopic composition is reported in $\delta$-notation relative to PeeDee belemnite as a standard:

$$
\delta^{13} \mathrm{C}=\left[\frac{\left({ }^{13} \mathrm{C} /{ }^{12} \mathrm{C}\right)_{\text {sample }}}{\left({ }^{13} \mathrm{C} /{ }^{12} \mathrm{C}\right)_{\text {standard }}}-1\right] 1000
$$

The isotopic composition of dissolved molecular $\mathrm{CO}_{2}$ $\left(\delta^{13} \mathrm{C}_{\mathrm{CO}_{2}}\right)$ was calculated from $\delta^{13} \mathrm{C}_{\mathrm{DIC}}$ following the equation provided by Rau et al. (1996) based on Mook et al. (1974):

$$
\delta^{13} \mathrm{C}_{\mathrm{CO}_{2}}=\delta^{13} \mathrm{C}_{\mathrm{DIC}}+23.644-\frac{9701.5}{T_{\mathrm{k}}}
$$

where $T_{\mathrm{k}}$ is the absolute temperature in kelvin.

The isotopic fractionation associated with photosynthetic $\mathrm{CO}_{2}$ fixation, $\varepsilon_{\mathrm{p}}$, was calculated relative to the isotopic composition of $\mathrm{CO}_{2}$ in the bulk medium according to Freeman \& Hayes (1992):

$$
\varepsilon_{\mathrm{p}}=\frac{\delta^{13} \mathrm{C}_{\mathrm{CO}_{2}}-\delta^{13} \mathrm{C}_{\mathrm{POC}}}{1+\delta^{13} \mathrm{C}_{\mathrm{POC}} / 1000}
$$

Growth rates. Determination of growth rates was based on either cell counts or POC measurements. The average $24 \mathrm{~h}$ growth rate was calculated according to

$$
\mu_{\mathrm{L}+\mathrm{D}}=\frac{\ln X_{j}-\ln X_{i-1}}{\Delta t}
$$

where $X_{i-1}$ and $X_{j}$ are concentrations of algal cells or POC at the beginning and at the end of the time interval $\Delta t$. Duplicate $20 \mathrm{ml}$ subsamples, preserved with Lugol's iodine (Edler 1979), where used for cell counts. Cell concentrations of Phaeodactylum tricornutum were determined with a Coulter 'Multisizer'. Cell concentrations of all other species were obtained from enumeration under the inverted microscope in duplicate on each subsample. Cell numbers in control bottles were determined from cell enumerations daily (slowly growing cells) or twice a day (rapidly growing cells) for at least 3 subsequent days parallel to each experimental run. From the experimental vessels, no subsamples were taken during incubation to avoid disturbance of the closed system, but cell concentrations were determined before and after incubation and calculated growth rates were compared to the control bottles.

Growth rates listed in Table 1 are based on concentrations of $\mathrm{POC}$ at the beginning $\left([\mathrm{POC}]_{0}\right)$ and the end $\left([\mathrm{POC}]_{1}\right)$ of incubation. $[\mathrm{POC}]_{1}$ was measured directly in the analysis of $\delta^{13} \mathrm{C}_{\mathrm{POC}}$ as described above. $[\mathrm{POC}]_{0}$ was calculated from the initial cell concentration and cellular carbon content. Growth rates determined from POC rather than cell concentrations permit the intro- 
duction of a term for dark carbon loss to account for differences in daylength between treatments. $\mu_{1}$ which represents the rate of photosynthetic carbon assimilation during the light period, was calculated according to

$$
\mu_{1}=\frac{(L+D) \mu_{\mathrm{L}+\mathrm{D}}}{L-D r}
$$

$L$ and $D$ are duration of the light and the dark period, respectively. The rate of carbon loss in the dark relative to the rate of carbon assimilation during the preceding photoperiod was assumed to equal $15 \%$ (Laws \& Bannister 1980), in which case $r$ equals 0.15 in Eq. (5).

\section{RESULTS}

Growth rates based on cell counts at the beginning and the end of incubation deviated by $\leq 0.1 \mathrm{~d}^{-1}$ from rates obtained from successive cell counts in pre-cultures. This indicates that no extended lag phase, which would affect calculation of growth rates from 2-point measurements, preceded exponential growth during the experiments. It becomes obvious from Table 1 that all species except Coscinodiscus wailesii exhibited only minor differences in $\mu_{L+D}$ between growth under continuous light or at a L/D cycle, i.e. cells were able to compensate for up to $8 \mathrm{~h}$ of darkness by enhanced rates of carbon assimilation during the photoperiod. Skeletonema costatum even grew at a somewhat higher rate in the $16: 8 \mathrm{~h} \mathrm{~L} / \mathrm{D}$ cycle than in continuous light. Only an extension of the dark period to $12 \mathrm{~h}$ resulted in a decrease in growth rate at comparable $\left[\mathrm{CO}_{2, \mathrm{aq}}\right]$. In S. costatum and Thalassiosira weissflogii, a decrease in $\left[\mathrm{CO}_{2, a q}\right]$ from ca 25 to $3 \mu \mathrm{mol} \mathrm{kg}^{-1}$ had little effect on $\mu_{L+D}$. As a result of relatively constant $\mu_{\mathrm{L}+\mathrm{D}}$ within each species, $\mu_{1}$ at a $16: 8$ or $18: 6 \mathrm{~h} \mathrm{~L} / \mathrm{D}$ cycle exceeded $\mu_{i}$ in continuous light by a factor of 1.6 or 1.4 when it is assumed that carbon loss in darkness accounts for $15 \%$ of the carbon assimilated during the preceding photoperiod.

We observed only small differences in $\delta^{13} \mathrm{C}_{\mathrm{CO}_{2}}(-10.0$ to $-10.7 \%$ ) between different batches of seawater used in our experiments, and no significant drift in $\delta^{13} \mathrm{C}$ of the carbon source occurred during the experiments listed in Table 1. The 7 phytoplankton species investigated can be divided into 2 groups according to their response in $\varepsilon_{\mathrm{p}}$ to variable $\mu_{3}$ at constant $\left[\mathrm{CO}_{2, \mathrm{aq}}\right]$. In Group I (Fig. 1a), $\varepsilon_{\mathrm{p}}$ during growth under continuous light was up to $6 \%$ higher than in a $16: 8 \mathrm{~h} \mathrm{~L} / \mathrm{D}$ cycle under otherwise identical conditions. In contrast, the 3 species of Group II (Fig. 1b) showed no response in $\varepsilon_{\mathrm{p}}$ to daylength or even somewhat higher $\varepsilon_{\mathrm{p}}$ values during growth in a L/D cycle. In both Fig. 1a \& b, the species are listed in the order of increasing cell size from the

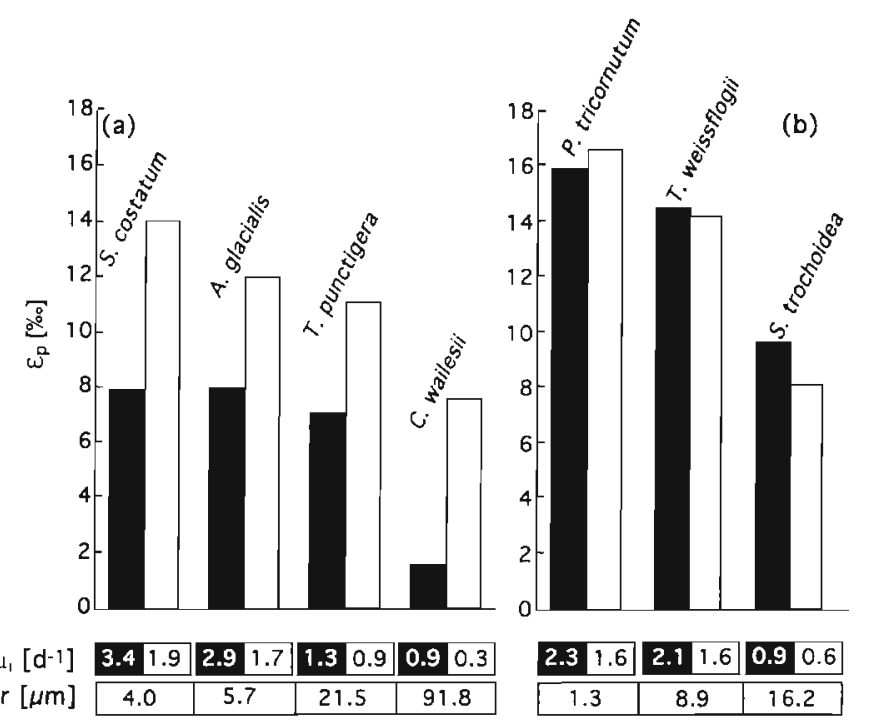

Fig. 1 Stable carbon isotope fractionation $\left(\varepsilon_{\mathrm{p}}\right)$ in continuous light (open bars) and in a 16:8 h light:dark cycle (18:6 h in Thalassiosira weissflogii, solid bars) at $\left[\mathrm{CO}_{2, \text { aq }}\right]>25 \mu \mathrm{mol} \mathrm{\textrm {kg } ^ { - 1 }}$ (see Table 1). Within each group, cell size of the species increases from left to right. Instantaneous growth rate $\left(\mu_{1}\right)$ and surface-equivalent spherical cell radius ( $r$ ) are shown in the lower panels. Results for Skeletonema costatum and $T$. weissflogii are mean values of $24 \mathrm{~h}$ time series. See Table 1 for full species' binomials; (a) Group I and (b) Group II

left to the right. As a general trend, isotopic fractionation decreases within each group as cell size increases.

In the time-series experiments with Skeletonema costatum and Thalassiosira weissflogi, the effect of $\mu_{\mathrm{i}}$ on $\varepsilon_{\mathrm{p}}$ at constant $\left[\mathrm{CO}_{2, \mathrm{aq}}\right]$ can be compared to the effect of variable $\left[\mathrm{CO}_{2, \mathrm{aq}}\right]$ on $\varepsilon_{\mathrm{p}}$ at constant $\mu_{i}$. Fig. 2 summarizes the results for $S$. costatum (Group I) grown at 4 combinations of $\left[\mathrm{CO}_{2, \mathrm{aq}}\right]$ and $\mathrm{L} / \mathrm{D}$ cycles, measured in $2 \mathrm{~h}$ intervals over a $24 \mathrm{~h}$ period. According to our definition of isotopic fractionation $(\mathrm{Eq}, 3), \varepsilon_{\mathrm{p}}$ refers to differences in the isotopic composition between carbon source and product due to photosynthetic carbon fixation. Thus it cannot be used to characterize processes occurring in darkness. Therefore, we show $\delta^{13} \mathrm{CpOC}$ instead of $\varepsilon_{p}$ values to describe diurnal trends in Fig. 2. Differences in $\delta^{13} \mathrm{C}$, however, are directly related to differences in $\varepsilon_{\mathrm{p}}$ because the isotopic composition of $\mathrm{CO}_{2}$ was identical in these experiments $\left(\delta^{13} \mathrm{C}_{\mathrm{CO}_{2}}=\right.$ $-10.7 \%$ ). For comparison of isotopic fractionation, we calculated $\varepsilon_{\mathrm{p}}$ of the respective treatment from $\delta^{13} \mathrm{C}_{\text {POC }}$ averaged over a $24 \mathrm{~h}$ period (Table 1 ). In S. costatum, we observed a marked effect of $\mu_{i}$ on $\varepsilon_{p}$ induced by the different L/D cycles. During growth under continuous light, fractionation was, on average, $6 \%$ higher than in the $16: 8 \mathrm{~h} \mathrm{~L} / \mathrm{D}$ cycle, corresponding to a decrease in $\mu_{\mathrm{i}}$ by ca $1.5 \mathrm{~d}^{-1}$. Since differences in $\mu_{1}$ between high and low $\left[\mathrm{CO}_{2, \mathrm{aq}}\right]$ were $\leq 0.2 \mathrm{~d}^{-1}$, it becomes obvious that changes in the carbonate system affected isotopic fractionation in S. costatum independent of growth rate. At 


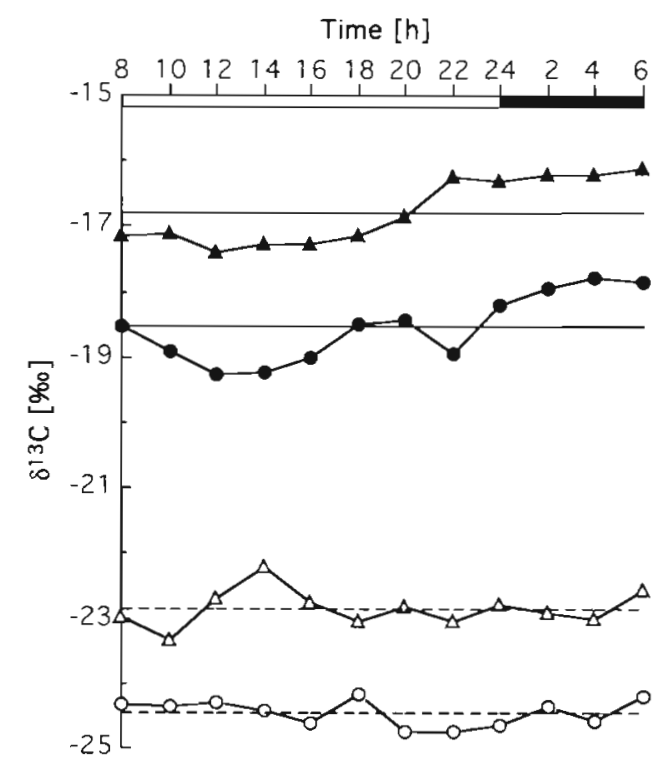

Fig. 2. Skeletonema costatum. Diurnal variation in the isotopic composition of POC $\left(\delta^{13} \mathrm{C}_{\mathrm{POC}}\right)$ over a $24 \mathrm{~h}$ period at $\mathrm{L} / \mathrm{D}$ cycles of $16: 8 \mathrm{~h}$ (closed symbols) versus $24: 0 \mathrm{~h}$ (open symbols)

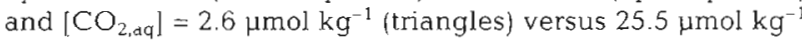
(circles). The solid bar indicates the dark period. Mean values of all samples are shown as a reference for each treatment (dashed lines for $\mathrm{L} / \mathrm{D}=24: 0 \mathrm{~h}$ )

a given daylength, $\varepsilon_{p}$ was, on average, 1.7 to $1.8 \%$ higher at $25.5 \mu \mathrm{mol} \mathrm{kg}{ }^{-1}\left[\mathrm{CO}_{2, \mathrm{aq}}\right]$ than at $2.6 \mu \mathrm{mol} \mathrm{kg}{ }^{-1}$ $\left[\mathrm{CO}_{2, \mathrm{aq}}\right]$ (Table 1). Thus the effect of variable $\mathrm{CO}_{2}$ on $\varepsilon_{\mathrm{p}}$ appeared to be small compared to the growth rate effect imposed by an $8 \mathrm{~h}$ difference in daylength. The offset in $\varepsilon_{p}$ between different $L / D$ cycles was of the same magnitude at both $\mathrm{CO}_{2}$ levels and persisted throughout a 24 h period.

Thalassiosira weissflogii represents a species of Group II showing no response in $\varepsilon_{p}$ to a daylengthrelated difference in $\mu_{\mathrm{i}}$ of $0.5 \mathrm{~d}^{-1}$ (Table 1, Fig. 3). Although this variation in $\mu_{i}$ is small compared to Skeletonema costatum as a result of a shorter dark period in the 18:6 $\mathrm{h} \mathrm{L/D}$ cycle (multiplying $\mu_{\mathrm{L}+\mathrm{D}}$ with 1.4 instead of 1.6$\}$ and lower absolute values of $\mu_{L+D}$, a noticeable difference in $\varepsilon_{\mathrm{p}}$ between continuous light and an $18: 6 \mathrm{~h} \mathrm{~L} / \mathrm{D}$ cycle would still be expected if $T$ weissflogii behaved in a similar way as $S$. costatum. The effect of $\mathrm{CO}_{2}$ concentration (3.5 vs $25.8 \mu \mathrm{mol} \mathrm{kg}{ }^{-1}$ ) on isotopic fractionation was slightly greater in $T$. weissflogii than in $S$. costatum with an average increase in $\varepsilon_{\mathrm{p}}$ by $2.6 \%$ $(18: 6 \mathrm{~h})$ or $2.2 \%(24: 0 \mathrm{~h})$ from low to high $\left[\mathrm{CO}_{2, \mathrm{arq}}\right]$.

In both species, $\delta^{13} \mathrm{C}_{\mathrm{POC}}$ tended to gradually increase during a $24 \mathrm{~h}$ period when grown in $16: 8$ or $18: 6 \mathrm{~h}$ L/D cycles (Figs. $2 \& 3$ ). No such trend was observed during growth under continuous light. The mean difference in $\delta^{13} \mathrm{C}_{\mathrm{POC}}$ between duplicate measurements was $0.2 \%$, which is approximately equal to the preci- sion of the Europa Scientific mass spectrometer used for $\delta^{13} \mathrm{C}_{\text {poc }}$ measurements. Therefore, we conclude that the observed amplitude of ca $1.5 \%$ in diurnal variation of $\delta^{13} \mathrm{C}_{\text {poc }}$ was significant, since it exhibited a systematic trend rather than random variation and could be reproduced in a 48 h experiment with Skeletonema costatum (Fig. 4). In both species we found $\delta^{13} C_{\text {POC }}$ values averaged over the light period to be significantly lower (Student's t-test, $p<0.01$ ) than in darkness. In contrast, $\delta^{13} \mathrm{C}_{\mathrm{poC}}$ values averaged over the first 16 or $18 \mathrm{~h}$ of a $24 \mathrm{~h}$ sampling period were not different from mean $\delta^{13} \mathrm{Cpoc}$ of the remaining samples in experiments under continuous light. Parallel trends at different $\mathrm{CO}_{2}$ concentrations provide additional evidence for diurnal changes in $\delta^{13} \mathrm{C}_{\mathrm{poc}}$. To further evaluate this diurnal pattern, we monitored $\delta^{13} \mathrm{C}_{\mathrm{poc}}$ of $S$. costatum in an additional experiment over $48 \mathrm{~h}$ in a 16:8 h L/D cycle. Fig. 4 indicates that minimum $\delta^{13} \mathrm{C}$ values again were obtained during the first hours of the light period and that the observed pattern was repeated during the following day.

Since the results for the $24 \mathrm{~h}$ time-series experiments were obtained independent of each other from 12 individual bottles per treatment, we can use the data to evaluate the replicability of $\delta^{13} \mathrm{C}_{\mathrm{POC}}$ measurements in our study. The narrow range of $\leq 1 \%$ variation in $\delta^{13} \mathrm{C}_{\mathrm{PoC}}$ under continuous light (Figs. $2 \& 3$ ) indicates that our experimental approach, in which cells were harvested at low cell densities during exponential

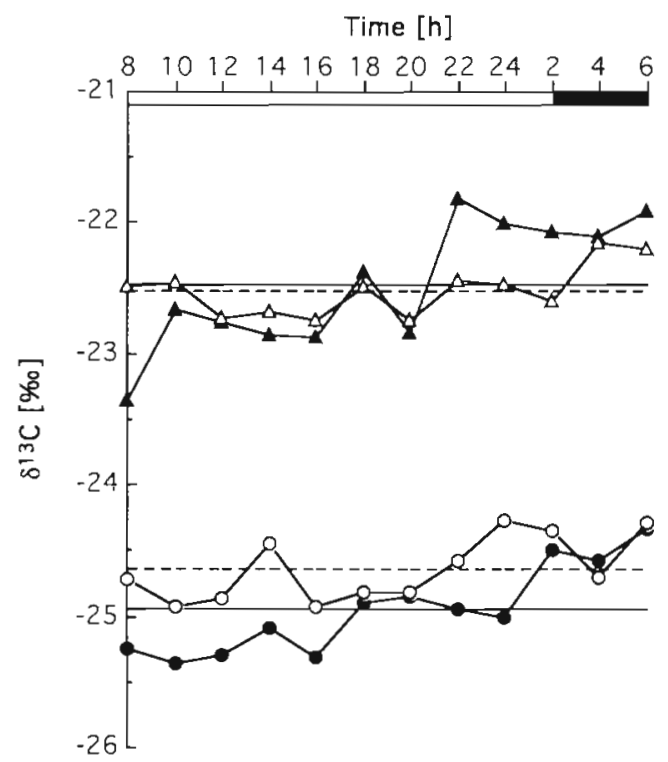

Fig. 3. Thalassiosira weissflogii. Diurnal variation in $\delta^{13} \mathrm{C}_{\mathrm{poc}}$ over a $24 \mathrm{~h}$ period at $\mathrm{L} / \mathrm{D}$ cycles of $18: 6 \mathrm{~h}$ (closed symbols) versus $24: 0 \mathrm{~h}$ (open symbols) and $\left[\mathrm{CO}_{2, \mathrm{aq}}\right]=3.5 \mu \mathrm{mol} \mathrm{kg}^{-1}$ (triangles) versus $25.8 \mu \mathrm{mol} \mathrm{kg}^{-1}$ (circles). Mean values of all samples are shown as a reference for each treatment (dashed lines for $\mathrm{L} / \mathrm{D}=24: 0 \mathrm{~h}$ ) 


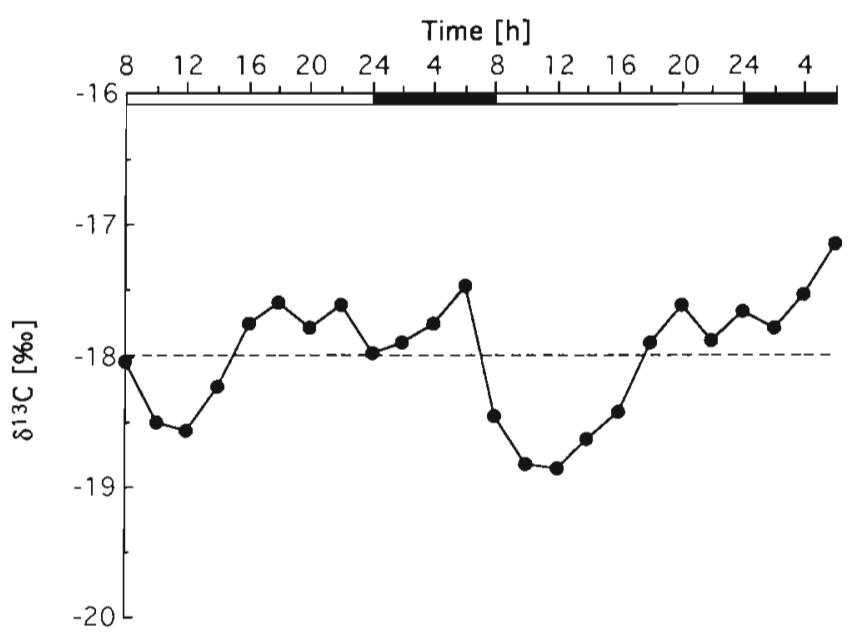

Fig. 4. Skeletonema costatum. Diurnal variation in $\delta^{13} \mathrm{C}_{\mathrm{pos}}$ over a $48 \mathrm{~h}$ period at a $\mathrm{L} / \mathrm{D}$ cycle of $16: 8 \mathrm{~h}$ and $\left[\mathrm{CO}_{2 \mathrm{dq}}\right]=$ $17.3 \mu \mathrm{mol} \mathrm{kg}{ }^{-1}$ (circles). Mean values of all samples are shown as a reference (dashed line)

growth, is well suited to derive reliable and highly reproducible fractionation values. Considering the accuracy of ca $0.2 \%$ in $\delta^{13} \mathrm{C}_{\mathrm{DIC}}$ measurements, we conclude that the 4 to $6 \%$ difference in isotopic fractionation observed within each species of Group I (Fig. 1) is not caused by random intraspecific variability but is clearly related to differences in irradiance cycles. Further evidence for daylength-dependent fractionation is provided by recent experiments of Burkhardt et al. (in press), who found a similar offset between $\varepsilon_{p}$ values, when Asterionella glacialis, Thalassiosira punctigera, and Coscinodiscus wailesii were incubated at 16:8 and 24:0 h L/D cycles at additional $\mathrm{CO}_{2}$ concentrations. As in this study, isotopic fractionation of Phaeodactylum tricornutum and Scrippsiella trochoidea was insensitive to differences in daylength at every experimental $\left[\mathrm{CO}_{2, \mathrm{aq}}\right]$

\section{DISCUSSION}

\section{Effect of daylength}

In contrast to other studies, in which changes in growth rate were achieved by nutrient limitation, variable light intensity, or differences in species composition of mixed phytoplankton assemblages (e.g. Fry \& Wainright 1991, Takahashi et al. 1991, Laws et al. 1995), the wide range of $\mu_{1}$ in the present study is a result of the ability of most species tested here to adjust their rate of carbon fixation to duration of the photoperiod. Such response in $\mu_{1}$ to daily light dose appears to be a common phenomenon among microalgae (Brand \& Guillard 1981).
Considering light effects on isotopic fractionation in phytoplankton, it makes a fundamental difference whether daily light dose is reduced by a longer dark period or by lower light intensities. During growth under high light conditions in a L/D cycle, organic carbon is produced at a high rate with sufficient light energy available for metabolic reactions. In contrast, an algal cell under continuous low light conditions may receive the same daily light dose under permanent energy limitation. Limited light supply may be of particular importance if an energy-consuming active transport step is involved in inorganic carbon acquisition, as has been suggested for several phytoplankton species (e.g. Badger \& Price 1992). As a result of physiological adaptation to low irradiance levels, marine algae are able to increase photosynthetic quantum yield which is not a parameter that correlates with daylength (Sakshaug \& Andresen 1986, Sakshaug et al. 1989). In contrast, adaptation of growth to extended dark periods requires higher photosynthetic rates during the light phase. Experiments by Mortain-Bertrand et al. (1987a,b, $1988 \mathrm{a}, \mathrm{b})$ indicate that the photoperiod might directly influence cellular activity of RUBISCO and thus the efficiency of algal cells to use the available inorganic carbon for assimilation into organic compounds.

Few experimental studies have investigated the effect of daylength on isotopic fractionation. In dense batch cultures, Thompson \& Calvert (1994) examined the combined effect of photon flux density and daylength on carbon isotope fractionation by the marine diatom Thalassiosira pseudonana. However, interpretation of their results is complicated because effects of light intensity and daylength were not treated separately, and observed trends were not consistent over the respective ranges. Leboulanger et al. (1995) compared the isotopic composition of 3 marine microalgae (Skeletonema costatum, Isochrysis galbana, Amphidinium operculatum), grown in batch culture under light-limitation with different L/D cycles. All species were enriched in ${ }^{13} \mathrm{C}$ by 1.5 to $3.2 \%$ when grown in a $12: 12 \mathrm{~h} \mathrm{~L} / \mathrm{D}$ cycle compared to continuous light. Assuming that $\delta^{13} \mathrm{C}_{\mathrm{DIC}}$ was identical between treatments and remained constant during incubation, the higher $\varepsilon_{\mathrm{p}}$ during growth under continuous light found by Leboulanger et al. (1995) is consistent with our results for the 4 diatom species belonging to Group I. As in our study, correction for the dark period yields higher $\mu_{i}$ compared to continuous light, and the decrease in $\varepsilon_{\mathrm{p}}$ thus correlates with an increase in $\mu_{\mathrm{i}}$.

\section{Effect of $\mathrm{CO}_{2}$ in relation to growth rate}

Skeletonema costatum and Thalassiosira weissflogii were used in experiments to test the effect of $\mathrm{CO}_{2}$ concentration on isotopic fractionation in Group I and 
Group II, respectively. Since a decrease in $\left[\mathrm{CO}_{2, \mathrm{aq}}\right]$ from 26 to $3 \mu \mathrm{mol} \mathrm{kg}^{-1}$ had only a small effect on growth rate in both $S$. costatum and $T$. weissflogii (Table 1), the effect of $\left[\mathrm{CO}_{2, \text { aq }}\right]$ on $\varepsilon_{\mathrm{p}}$ at constant $\mu_{\mathrm{i}}$ could be directly compared to the effect of $\mu_{1}$ on $\varepsilon_{\mathrm{p}}$ at constant $\left[\mathrm{CO}_{2, a q}\right]$. In both species, $\varepsilon_{\mathrm{p}}$ decreased by $<3 \%$ from high to low $\left[\mathrm{CO}_{2, \mathrm{aq}}\right]$. This change in $\varepsilon_{\mathrm{p}}$ is small compared to the $>10 \%$ latitudinal variation in $\varepsilon_{\mathrm{p}}$ of plankton in the ocean, attributed by Rau et al. (1989) to $\mathrm{CO}_{2}$ concentrations ranging from ca 5 to $25 \mu \mathrm{mol} \mathrm{kg}^{-1}$. In contrast, an increase in $\mu_{\mathrm{i}}$ in response to a shorter daily photoperiod caused a decrease in $\varepsilon_{\mathrm{p}}$ by ca $6 \%$ in $S$. costatum, indicating that daylength-related growth rate effects on isotopic fractionation can be greater than $\mathrm{CO}_{2}$ effects. If the dominant phytoplankton species in the ocean show a response of $\varepsilon_{\mathrm{p}}$ to growth rate similar to that of the Group I organisms in our study, the difference in $\mu_{\mathrm{i}}$ between lower latitudes (short days, high temperature) and higher latitudes (long days, low temperature) may contribute significantly to the observed latitudinal variation in isotopic composition of natural plankton assemblages in the ocean. The potential importance of phytoplankton growth rate in contributing to field variability of isotopic fractionation has previously been acknowledged in several other studies (e.g. Francois et al. 1993, Goericke \& Fry 1994, Laws et al. 1995, 1997).

\section{Consequences for the $\varepsilon_{\mathrm{p}}$ versus $\mu_{\mathrm{i}}\left[\mathrm{CO}_{2, \mathrm{aq}}\right]$ relationship}

According to existing models of isotopic fractionation in marine phytoplankton (e.g. Francois et al. 1993, Laws et al. 1995, 1997, Rau et al. 1996), both an increase in $\mu_{i}$ and a decrease in $\left[\mathrm{CO}_{2, \mathrm{aq}}\right]$ would lower $\varepsilon_{\mathrm{p}}$. For algal cells of similar carbon content and cell geometry, a linear inverse relationship is predicted between $\varepsilon_{p}$ and $\mu_{\mathrm{i}} /\left[\mathrm{CO}_{2, \text { aq }}\right]$ if inorganic carbon acquisition occurs exclusively by diffusive uptake of $\mathrm{CO}_{2}$. Even if $\mathrm{CO}_{2}$ is taken up by an active transport process in addition to passive diffusion, $\varepsilon_{\mathrm{p}}$ varies as a linear function of $\mu_{\mathrm{i}} /\left[\mathrm{CO}_{2, \mathrm{aq}}\right]$ as long as the active $\mathrm{CO}_{2}$ uptake is proportional to intracellular carbon demand or growth rate (Popp et al. 1998). Another factor which may cause a progressive decrease in $\varepsilon_{\mathrm{p}}$ with decreasing $\left[\mathrm{CO}_{2, \mathrm{aq}}\right]$ is the gradual induction of active $\mathrm{HCO}_{3}{ }^{-}$ uptake towards lower $\mathrm{CO}_{2}$ concentrations. In fact, as argued by Keller \& Morel (1999), the observed $\varepsilon_{\mathrm{p}}$ versus $\mu_{\mathrm{i}} /\left[\mathrm{CO}_{2, \mathrm{aq}}\right]$ correlation does not permit differentiation between active uptake of $\mathrm{CO}_{2}$ and of $\mathrm{HCO}_{3}{ }^{-}$.

In our study, daylength-dependent fractionation in Group I is consistent with the predicted increase in $\varepsilon_{\mathrm{p}}$ upon a decrease in $\mu_{\mathrm{i}}$ at constant $\left[\mathrm{CO}_{2, a q}\right]$. Both passive diffusion of $\mathrm{CO}_{2}$ and/or active uptake of inorganic carbon may have accounted for the observed trends. On the other hand, constant fractionation independent of daylength-related changes in $\mu_{\mathrm{i}}$ indicates that diffusive $\mathrm{CO}_{2}$ uptake may not be the dominant pathway of $\mathrm{C}$ acquisition in Group II species even at the high $\mathrm{CO}_{2}$ concentrations in our experiments. Constant fractionation at variable $\mu_{1}$ is expected if changes in the uptake rate of $\mathrm{CO}_{2}$ or $\mathrm{HCO}_{3}^{-}$are proportional to changes in carbon fixation rate, mediated by regulated active carbon transport.

The species-specific response to different irradiance cycles has 2 important implications for the interpretation of isotope data. First, if a significant portion of the phytoplankton species in the field adjusts its mode of inorganic carbon uptake in a way that large variations in $\mu_{1}$ are not reflected in isotopic fractionation, an $\varepsilon_{\mathrm{p}}$ versus $\mu_{\mathrm{i}} /\left[\mathrm{CO}_{2, a q}\right]$ relationship is not applicable for the determination of growth rate or $\mathrm{CO}_{2}$ concentration from isotope data. Second, the results for Phaeodactylum tricornutum indicate that even in a single algal species the dependence of $\varepsilon_{\mathrm{p}}$ on the growth rate may differ, contingent upon the factor controlling $\mu_{\mathrm{i}}$. While $P$. tricornutum was insensitive to daylength-related changes in $\mu_{\mathrm{i}}$ in our study, lower growth rates enforced by $\mathrm{N}$-limited conditions can result in significantly higher fractionation in this species at comparable $\left[\mathrm{CO}_{2, a q}\right]$ (Laws et al. 1995).

Based on theoretical consideration, cell surface area and either cellular carbon content or cell volume affect isotopic fractionation (e.g. Goericke et al. 1994, Laws et al. 1995, Rau et al. 1996), which has been demonstrated experimentally by Popp et al. (1998). Our results are consistent with their observation that larger organisms fractionate less at comparable growth rates.

\section{Diurnal variation}

Carbon metabolism of algal cells is characterized by carboxylation and decarboxylation reactions, catalyzed and regulated by specific enzymes. Most of these reactions involve isotopic fractionation of up to $40 \%$ (O'Leary et al. 1992, Goericke et al. 1994) and may thus affect the isotopic composition of algal cells. In marine diatoms, inorganic carbon is fixed predominantly by RUBISCO (Mortain-Bertrand et al. 1987a, b, 1988a, b, Descolas-Gros \& Oriol 1992). Next to photosynthetic $C$ fixation by RUBISCO, the most important carboxylation reaction is fixation of inorganic carbon by 及-carboxylating enzymes, typically PEP-carboxylase (PEPC) or PEP-carboxykinase (PEPCK) (Raven 1997). Since both enzymes use phosphoenol pyruvate (PEP) as a substrate, which is derived from photosynthesis (Calvin cycle), $\beta$-carboxylation is ultimately coupled to the presence of light and represents no net fixation of inorganic carbon. Batch culture experiments with 
Skeletonema costatum show that the ratio of $\beta$-carboxylation to RUBISCO activity remains very low $(<1 \%)$ in the early exponential growth phase (Descolas-Gros \& Fontugne 1985, Descolas-Gros \& Oriol 1992). We thus consider $\beta$-carboxylation unlikely to account for the diurnal variability in $\delta^{13} \mathrm{C}_{\text {Poc }}$ observed in our study.

Decarboxylation reactions are central to both catabolic pathways (mobilization of energy) and anabolic pathways (biosynthesis). In darkness, when RUBISCO is inactive and no net fixation of inorganic carbon occurs, carbohydrate reserves are used to fuel metabolic reactions and to provide the carbon skeleton for major biochemical compounds such as proteins and lipids. The effect of decarboxylation reactions on $\delta^{13} C_{\text {POC }}$ should therefore be most pronounced during the dark period, when carbon fluxes are dominated by respiratory activity. Isotopic fractionation associated with decarboxylation can range from 9 to $32 \%$ (for reviews see Goericke et al. 1994, Raven 1997) but will affect $\delta^{13} \mathrm{C}_{\mathrm{POC}}$ only if respired $\mathrm{CO}_{2}$ is not efficiently refixed in other cellular substrates. Furthermore, $\delta^{13} \mathrm{C}_{\mathrm{poc}}$ is not affected when carbon compounds of similar isotopic composition as POC are completely respired to $\mathrm{CO}_{2}$ in catabolic processes, in which case $\delta^{13} \mathrm{C}_{\mathrm{CO}_{2}}$ would not differ from $\delta^{13} \mathrm{C}$ of the substrate. On the other hand, complete degradation of compounds that deviate from the average isotopic composition of algal carbon may lead to changes in $\delta^{13} \mathrm{C}_{\mathrm{Poc}}$ even when no fractionation occurs during decarboxylation.

In contrast to growth under continuous light, alternating L/D periods lead to partial synchronization of cell division in phytoplankton cells (e.g. Nelson \& Brand 1979, Chisholm 1981, Harding et al. 1981, Prézelin 1992). The timing of maximum cell division seems to depend on the respective growth conditions. For example, Skeletonema costatum exhibited maximum division rates during the light period in some studies (Jørgensen 1966, Cosper 1982) but during the dark period in others (Eppley et al. 1971). In our experiments, successive cell counts indicated that the majority of cell divisions occurred during the dark period (data not shown). We suggest that the small but significant variation in $\delta^{13} \mathrm{C}_{\mathrm{POC}}$ during the photoperiod is mainly driven by variable rates of carbon fixation. If synchronized cell division occurs near the end of the dark period, it is likely to be followed by a period of somewhat lower metabolic activity. In experiments with $S$. costatum, Burkhardt et al. (1999) monitored the diurnal variability of the $C: N$ ratio. A pronounced increase in $\mathrm{C}: \mathrm{N}$, reflecting accumulation of carbohydrates in the light, may be taken as an indication for high rates of carbon assimilation. Such an increase in $\mathrm{C}: \mathrm{N}$ was observed in $S$. costatum only in the second half of a $16 \mathrm{~h}$ photoperiod, coinciding with an increase in $\delta^{13} \mathrm{C}_{\text {poc }}$. These observations are consistent with the predicted decrease in fractionation upon an increase in the rate of carbon fixation.

The drop in $\delta^{13} \mathrm{C}_{\mathrm{POC}}$ during the last hours of darkness, proceeding into the first half of the photoperiod, may be associated with a major metabolic event such as synchronized cell division. Fractionation associated with carboxylation/decarboxylation reactions, complete decarboxylation of ${ }^{13} \mathrm{C}$-rich organic compounds, or the loss of ${ }^{13} \mathrm{C}$-enriched dissolved organic carbon from the cell would lead to ${ }^{12} \mathrm{C}$ enrichment of $\mathrm{POC}$ in the dark. The available information, however, prevents identification of causes for the observed trend. While metabolic processes such as respiration and biosynthesis may involve large fractionation by the respective enzymes, the overall effect on $\delta^{13} \mathrm{C}_{\mathrm{poc}}$ appears to be small, as indicated by the daily amplitude of algal isotopic composition of $\leq 1.5 \%$.

\section{CONCLUSIONS}

Incubation of phytoplankton at different $L / D$ cycles provides the means to test the effect of growth rate on isotopic fractionation independent of limitation by light intensity or nutrient supply. Laboratory experiments with 7 marine phytoplankton species revealed that duration of the daily photoperiod had a significant impact on $\varepsilon_{\mathrm{p}}$ in 4 of the species tested. We attribute this variation in $\varepsilon_{\mathrm{p}}$ to the ability of the cells to accelerate the rate of photosynthetic carbon fixation during growth at shorter daylengths. Such a physiological adaptation may be mediated by an increase in cellular activity of RUBISCO. In spite of daylength-related differences in $\mu_{\mathrm{i}}$, no effect of daylength on isotopic fractionation was found in 3 of the species tested, indicating that at least 2 groups of marine microalgae exist which respond differently to variable irradiance cycles. Regulated active uptake of inorganic carbon may be responsible for the observed pattern.

Our data provide evidence that $\mu_{\mathrm{i}}$-dependent fractionation is both species-specific and dependent on the factor controlling growth rate. Thus, a general relationship between $\varepsilon_{\mathrm{p}}$ and $\mu_{\mathrm{i}} /\left[\mathrm{CO}_{2, \mathrm{aq}}\right]$ may not exist. These results suggest that in situ growth rates of phytoplankton cannot be estimated from a $\varepsilon_{\mathrm{p}}$ versus $\mu_{\mathrm{i}} /\left[\mathrm{CO}_{2, \mathrm{aq}}\right]$ relationship based on bulk samples of POC, even if other parameters such as cell size and cell geometry are well constrained. It needs to be investigated whether the use of species-specific or groupspecific biomarkers, as for example alkenones of coccolithophorids, can sufficiently reduce the complexity of interpreting isotope data in paleo-reconstruction, as has been suggested in previous studies (e.g. Jasper \& Hayes 1990, 1994, Francois et al. 1993, Goericke \& Fry 1994). 
Acknowledgements. We thank A. Dauelsberg, C. Hartmann, C. Langreder, A. Mackensen, K.-U. Richter, and G. Traue for technical support. B. Kroon and D. Wolf-Gladrow provided valuable comments on earlier versions of the manuscript. This is Publication No. 1583 of the Alfred Wegener Institute for Polar and Marine Research. This research was partly supported by the project 'Marine Ecosystem Regulation: Trace Metal and Carbon Dioxide Limitation' (MERLIM) of the European Union within the Marine Science and Technology Program under Contract No. MAS3-CT95-0005

\section{LITERATURE CITED}

Badger MR, Price GD (1992) The $\mathrm{CO}_{2}$ concentrating mechanism in cyanobacteria and microalgae. Physiol Plant 84 กก6 - 615

Bidigare RR, Fluegge A, Freeman KH, Hanson KL, Hayes JM, Hollander D, Jasper JP, King LL, Laws EA, Milder J. Millero FJ, Pancost R, Popp BN, Steinberg PA, Wakeham SG (1997) Consistent fractionation of ${ }^{13} \mathrm{C}$ in nature and in the laboratory: growth rate effects in some haptophyte algae. Global Biogeochem Cycles 11:279-292

Brand LE, Guillard RRL (1981) The effects of continuous light and light intensity on the reproduction rates of twenty-two species of marine phytoplankton. J Exp Mar Biol Ecol 50: $119-132$

Burkhardt S, Riebesell U (1997) $\mathrm{CO}_{2}$ availability affects elemental composition (C:N:P) of the marine diatom Skeletonema costatum. Mar Ecol Prog Ser 155:67-76

Burkhardt S, Zondervan I, Riebesell U (1999) Effect of $\mathrm{CO}_{2}$ concentration on C:N:P ratio in marine phytoplankton: a species comparison. Limnol Oceanogr 44:683-690

Burkhardt S, Riebesell U, Zondervan I (in press) Effects of growth rate, $\mathrm{CO}_{2}$ concentration, and cell size on the stable carbon isotope fractionation in marine phytoplankton. Geochim Cosmochim Acta

Chisholm SW (1981) Temporal patterns of cell division in unicellular algae. In: Platt T (ed) Physiological bases of phytoplankton ecology. Can Bull Fish Aquat Sci 210:150-181

Cosper $E$ (1982) Influence of light intensity on diel variations in rates of growth, respiration and organic release of a marine diatom: comparison of diurnally constant and fluctuating light. J Plankton Res 4:705-724

Descolas-Gros C, Fontugne MR (1985) Carbon fixation in marine phytoplankton: carboxylase activities and stable carbon-isotope ratios; physiological and paleoclimatological aspects. Mar Biol 87:1-6

Descolas-Gros C, Oriol L (1992) Variations in carboxylase activity in marine phytoplankton cultures. $\beta$-carboxylation in carbon flux studies. Mar Ecol Prog Ser 85:163-169

Deuser WC; Degens ET, Guillard RRL (1968) Carbon isotope relationships between plankton and sea water. Geochim Cosmochim Acta 32:657-660

Edler L (1979) Recommendations for marine biological studies in the Baltic Sea. Phytoplankton and chlorophyll. Baltic Mar Biol Publ 5:1-38

Eppley RW, Rogers JN, McCarthy JJ, Sournia JJ (1971) Light:dark periodicity in nitrogen assimilation of the marine phytoplankters Skeletonema costatum and CoccoLithus huxleyi in $\mathrm{N}$-limited chemostat cultures. J Phycol 7 $150-154$

Francois R, Altabet MA, Goericke R (1993) Changes in the $\delta^{13} \mathrm{C}$ of surface water particulate organic matter across the subtropical convergence in the SW Indian Ocean. Global Biogeochem Cycles 7:627-644

Freeman KH. Hayes JM (1992) Fractionation of carbon isotopes by phytoplankton and estimates of ancient $\mathrm{CO}_{2}$ levels. Global Biogeochem Cycles 6:185-198

Fry B, Wainright SC (1991) Diatom sources of ${ }^{13} \mathrm{C}$-rich carbon in marine food webs. Mar Ecol Prog Ser 76:149-157

Goericke R, Fry B (1994) Variations of marine plankton $\delta^{13} \mathrm{C}$ with latitude, temperature, and dissolved $\mathrm{CO}_{2}$ in the world ocean. Global Biogeochem Cycles 8:85-90

Goericke R, Montoya JP, Fry B (1994) Physiology of isotopic fractionation in algae and cyanobacteria. In: Lajhta K. Michener RH (eds) Stable isotopes in ecology and environmental science. Blackwell Scientific Publications, Cambridge, MA, p 187-221

Guillard RRL, Ryther JH (1962) Studies of marine planktonic diatoms. Can J Microbiol 8:229-239

Harding LW Jr, Meeson BW. Prézelin BB, Sweeney BM (1981) Diel periodicity of photosynthesis in marine phytoplankton. Mar Biol 61:95-105

Jasper JP, Hayes JM (1990) A carbon isotope record of $\mathrm{CO}_{2}$ levels during the late Quaternary. Nature 347:462-464

Jasper JP, Hayes JM (1994) Reconstruction of paleoceanic $\mathrm{pCO}_{2}$ levels from carbon isotopic compositions of sedimentary biogenic components. In: Zahn R, Pedersen TF, Kaminski MA, Labeyrie L (eds) Carbon cycling in the glacial ocean: constraints on the ocean's role in global change. NATO ASI Series 1, Vol 17. Springer-Verlag, Berlin, p 323-341

Jasper JP, Hayes JM, Mix AC, Prahl FG (1994) Photosynthetic fractionation of ${ }^{13} \mathrm{C}$ and concentrations of dissolved $\mathrm{CO}_{2}$ in the central equatorial Pacific during the last 255,000 years. Paleoceanography 9:781-798

Johnston AM (1996) The effect of environmental variables on ${ }^{13} \mathrm{C}$ discrimination by two marine phytoplankton. Mar Ecol Prog Ser 132:257-263

Jorgensen EG (1966) Photosynthetic activity during the life cycle of synchronous Skeletonema cells. Physiol Plant 19: $789-799$

Keller K, Morel FMM (1999) A model of carbon isotopic fractionation and active carbon uptake in phytoplankton. Mar Ecol Prog Ser 182:295-298

Kukert H Riebesell U (1998) Phytoplankton carbon isotope fractionation during a diatom spring bloom in a Norwegian fjord. Mar Ecol Prog Ser 173:127-137

Laws EA, Bannister TT (1980) Nutrient- and light-limited growth of Thalassiosira fluviatilis in continuous culture, with implications for phytoplankton growth in the ocean. Limnol Oceanogr 25:457-473

Laws EA, Popp BN, Bidigare RR, Kennicutt MC II, Macko SA (1995) Dependence of phytoplankton carbon isotopic composition on growth rate and $\left[\mathrm{CO}_{2}\right] \mathrm{aq}$ : theoretical considerations and experimental results. Geochim Cosmochim Acta 59:1.131-1138

Laws EA, Popp BN, Bidigare RR (1997) Effect of growth rate and $\mathrm{CO}_{2}$ concentration on carbon isotopic fractionation by the marine diatom phaeodactylum tricornutum. Limnol Oceanogr 42:1552-1560

Leboulanger C, Descolas-Gros C, Fontugne MR, Bentaleb I, Jupin $\mathrm{H}$ (1995) Interspecific variability and environmental influence on particulate organic carbon $\delta^{13} \mathrm{C}$ in cultured marine phytoplankton. J Plankton Res 17:2079-2091

Mackensen A, Hubberten HW, Scheele N, Schlitzer R (1996) Decoupling of $\delta^{13} \mathrm{C \Sigma CO}_{2}$ and phosphate in recent Weddell Sea deep and bottom water: implications for glacial Southern Ocean paleoceanography. Paleoceanography 11:203-215

Mehrbach $\mathrm{C}$, Culberson $\mathrm{CH}_{\text {, Hawley JE, Pytkowicz RM }}$ (1973) Measurement of the apparent dissociation constants of carbonic acid in seawater at atmospheric pressure. Limnol Oceanogr 18:897-907 
Mook WG, Bommerson JC, Staverman WH (1974) Carbon isotope fractionation between dissolved bicarbonate and gaseous carbon dioxide. Earth Planet Sci Lett 22:169-176

Mortain-Bertrand A, Descolas-Gros C, Jupin H (1987a) Shortterm ${ }^{14} \mathrm{C}$ incorporation in Skeletonema costatum (Greville) Cleve (Bacillariophyceae) as a function of light regime. Phycologia 26:262-269

Mortain-Bertrand A, Descolas-Gros C, Jupin H (1987b) Stimulating effect of light-to-dark transitions on carbon assimilation by a marine diatom. J Exp Mar Biol Ecol 112:11-26

Mortain-Bertrand A, Descolas-Gros C, Jupin H (1988a) Pathway of dark inorganic carbon fixation in two species of diatoms: influence of light regime and regulator factors on diel variations. J Plankton Res 10:199-217

Mortain-Bertrand A, Descolas-Gros C, Jupin H (1988b) Growth, photosynthesis and carbon metabolism in the temperate marine diatom Skeletonema costatum adapted to low temperature and low photon-flux density. Mar Biol 100:135-141

Nelson DM, Brand LE (1979) Cell division periodicity in 13 species of marine phytoplankton on a light:dark cycle. J Phycol 15:67-75

O'Leary MH, Madhavan S, Paneth P (1992) Physical and chemical basis of carbon isotope fractionation in plants. Plant Cell Environ 15:1099-1104

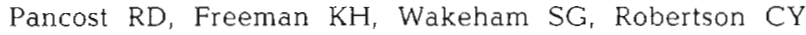
(1997) Controls on carbon isotope fractionation in the Peru upwelling region. Geochim Cosmochim Acta 61. 4983-4991

Popp BN, Laws EA, Bidigare RR, Dore JE, Hanson KL, Wakeham SG (1998) Effect of phytoplankton cell geometry on carbon isotopic fractionation. Geochim Cosmochim Acta 62:69-77

Prézelin BB (1992) Diel periodicity in phytoplankton productivity. Hydrobiologia 238:1-35

Rau GH (1994) Variations in sedimentary organic $\delta^{13} \mathrm{C}$ as a proxy for past changes in ocean and atmospheric $\mathrm{CO}_{2}$ concentrations. In: Zahn $\mathrm{R}$, Pedersen $\mathrm{TF}$, Kaminski MA, Labeyrie L (eds) Carbon cycling in the glacial ocean: constraints on the ocean's role in global change. NATO ASI Series 1, Vol 17. Springer-Verlag, Berlin, p 307-321

Rau GH, Sweeney RE, Kaplan IR (1982) Plankton ${ }^{13} \mathrm{C} /{ }^{12} \mathrm{C}$ ratio changes with latitude: differences between northern and southern oceans. Deep-Sea Res 29:1035-1039

Editorial responsibility: Otto Kinne (Editor), Oldendorf/Luhe, Germany
Rau GH, Takahashi T, des Marais DJ (1989) Latitudinal variations in plankton $\delta^{13} \mathrm{C}$ : implications for $\mathrm{CO}_{2}$ and productivity in past oceans. Nature 341:516-518

Rau GH, Takahashi T, des Marais DJ, Repeta DJ, Martin JH (1992) The relationship between $\delta^{13} \mathrm{C}$ of organic matter and $\left[\mathrm{CO}_{2}(\mathrm{aq})\right]$ in ocean surface water: data from a JGOFS site in the northeast Atlantic Ocean and a model. Geochim Cosmochim Acta 56:1413-1419

Rau GH, Riebesell U, Wolf-Gladrow D (1996) A model of photosynthetic ${ }^{13} \mathrm{C}$ fractionation by marine phytoplankton based on diffusive molecular $\mathrm{CO}_{2}$ uptake Mar Ecol Prog Ser 133:275-285

Rau GH, Riebesell U, Wolf-Gladrow D (1997) $\mathrm{CO}_{2 a q}$-dependent photosynthetic ${ }^{13} \mathrm{C}$ fractionation in the ocean: a model versus measurements. Global Biogeochem Cycles $11: 267-278$

Raven JA (1997) Inorganic carbon acquisition by marine autotrophs. Adv Bot Res 27:85-209

Sackett WM, Eckelmann WR, Bender ML, Bé AWH (1965) Temperature dependence of carbon isotope composition in marine plankton and sediments. Science 148:235-237

Sackett WM, Eadie BJ, Exner ME (1974) Stable isotope composition of organic carbon in recent Antarctic sediments In: Tissot B, Biener $F$ (eds) Advances in organic geochemistry. Pergamon, Oxford, p 661-671

Sakshaug E. Andresen K (1986) Effect of light regime upon growth rate and chemical composition of a clone of Skeletonema costatum from the Trondheimsfjord, Norway J Plankton Res 8:619-637

Sakshaug E, Andresen K, Kiefer DA (1989) A steady state description of growth and light absorption in the marine planktonic diatom Skeletonema costatum. Limnol Oceanogr 34:198-205

Strathmann RR (1967) Estimating the organic carbon content of phytoplankton from cell volume or plasma volume. Limnol Oceanogr 12:411-418

Takahashi K, Wada E, Sakamoto M (1991) Relationship between carbon isotope discrimination and the specific growth rate of green alga Chlamydomonas reinhardtii. Jpn J Limnol 52:105-112

Thompson PA, Calvert SE (1994) Carbon-isotope fractionation by a marine diatom: the influence of irradiance, daylength, $\mathrm{pH}$, and nitrogen source. Limnol Oceanogr 39; $1835-1844$

Submitted: October 2, 1998; Accepted: May 5, 1999

Proofs received from author(s): July 2, 1999 